\title{
PHYTOCHEMICAL STUDIES ON GROWTH, YIELD AND CHEMICAL CONSTITUENTS OF FENNEL PLANTS (Foeniculum vulgare Mill) AS EFFECTED BY ANTIOXIDANTS SUBSTANCES UNDER SALINE RECLAIMED SOIL CONDITIONS.
}

\author{
Matter, F. M. A.
}

Dept. of Hort. Fac. of Agric. Fayoum University. Egypt.

\section{ABSTRACT:}

In pot experiment were carried out in the Experimental farm, Faculty of Agriculture, Fayoum University, during two successive seasons of 2006/2007 and 2007/2008 to investigate the effect antioxidants, namely, ascorbic acid, citric acid and vitamin $\mathrm{B}$ each alone, at the rates of, 100,250 and $500 \mathrm{ppm}$ on improving the growth, yield and some chemical constituents of fennel plants grown under saline reclaimed soil conditions.

The obtained results showed that the treated fennel plants with ascorbic acid, citric acid and vitamin B reduced the harmful effect of soil salinity and improved plant growth characters expressed as plant height, number of branches, fresh and dry weights of herb plant ${ }^{-1}$, number of umbels plant ${ }^{-1}$, diameter of umbel, fresh and dry weights of umbels plant ${ }^{-1}$ and weight of seeds plant ${ }^{-1}$, as well as, yield of essential oil, total chlorophylls and carotenoids content, total carbohydrate and $\mathrm{N}$ percentage. Generally, the highest rate of antioxidants substances (500 ppm) gave the best results on the above characters which studied and were arranged as vitamin B followed by ascorbic acid then citric acid.

Key words: Ascorbic, Citric acid and Vitamin B, fennel, Growth, Essential oil.

\section{INTRODUCTION}

Nowadays, more tendency for cultivation of aromatic plants has shown in Egypt in order to cover the increasing demands of the local industries and it is a good source of hard currency, also, the medicinal plants considered an important source of income in agriculture section of the national economy in many countries.

Fennel (Foeniculum vulgare Mill.) is an essential oil producing aromatic plants that belongs to the Apiaceae family. Essential oil of fennel $(0.69$ and $4.6 \%)$ is used as a flavor and aromatic agent in breads, soups and other food products. Aromatherapy and pharmaceutical industries utilize fennel essential oil. Research has shown that the growth of some bacteria can be inhibited by essential oil of fennel (Marotti et al., 1994).

The harmful influence of salinity on plant growth and metabolism was attributed, principally, to the enhanced $\mathrm{Na}^{+}$uptake which causes ion excess inplant tissues (Greenway and Munns,1980 and Abbas et al.,1991) one of the primary effects of increasing salinity in the growth medium is inhibition of $\mathrm{K}^{+}, \mathrm{Ca}^{+}$and $\mathrm{NO}^{+}$uptake by plant roots (Mass, 1986). Also, it is well established that salinity stress damages plant cells through production of reactive oxygen species including superoxide, hydrogen peroxide, hydroxyl anions and singlet oxygen (Scandalios, 1977). On the other hand, some researches have been made to alleviate the disturbances in plant metabolism excreted by salinity stress. It has been suggested that some antioxidants may help to overcome some of these inhibitory effects.

Fayoum J. Agric. Res. \& Dev., Vol.23, No.1,(B). January, 2009 
Ascorbic acid, citric and vitamin B are an important antioxidants defense in plant cells (Foyer and Halliwell, 1976) to protect them by scavenging the reactive oxygen species. It also, stimulates respiration activities, cell division and many enzymes activities (Innocenti $\boldsymbol{e t}$ al., 1990 and Rautenkranz et al., 1994).

Recently, the investigations tendency to use of natural and safety substances such as antioxidants for enhancing growth and productivity of many crops, since, citric, ascorbic acid and vitamin B has synergistic effects on growth, flowering, yield of seeds and oil and chemical constituents under favorable and un favorable environmental conditions i.e. salinity such as, Rady (2006) on sunflower plants found that the treated plants with ascorbic acids foliar spray treatments, significantly increased the growth, yield of seeds and oil and some chemical constituents in both tested seasons. The same trend was recorded by Mohamed and Naguib (2002) on fenugreek, Abdullahi et al. (2004) on soybean, Bardisi (2004) on garlic, Ahmed (2005) on Majorana hortensis, Al-Shareif (2006) on caraway and Abd El-Latif (2007) on borage.

This study was aimed to investigate the effect of ascorbic, citric acid and vitamin B on reducing the harmful effect of soil salinity and improving the vegetative growth, seed yield and oil and chemical constituents of fennel plants grown under saline soil conditions.

\section{MATERIALS AND METHODS}

The current investigation was conducted on a pots experiment during the two successive growing seasons of 2006/2007 and 2007/2008 at the Experimental Farm, Faculty of Agriculture, Fayoum University to study the effect of ascorbic, citric acid and vitamin B on the vegetative growth, seed yield and essential oil of fennel plants.

The mechanical and chemical analysis of soil used was carried out according to Olsen and Sommers, (1982) and Page et al., (1982).

Table (1): Physical and chemical characteristics of the studied soil.

\begin{tabular}{|c|c|c|c|c|c|c|c|c|c|c|c|}
\hline \multirow[t]{2}{*}{ 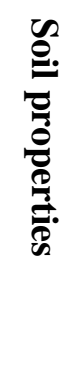 } & 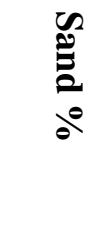 & 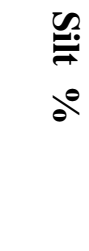 & $\begin{array}{l}\frac{\Omega}{2} \\
\frac{2}{2} \\
0\end{array}$ & 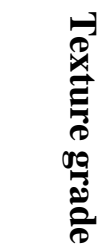 & $\bar{x}$ & $\begin{array}{l}2 \\
\hat{2} \\
\hat{0} \\
\hat{z}\end{array}$ & 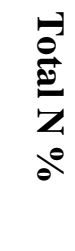 & $\begin{array}{l}0 \\
0 \\
0 \\
0 \\
0\end{array}$ & $\begin{array}{l}\overrightarrow{0} \\
\frac{0}{3} \\
\frac{\pi}{\pi} \\
09\end{array}$ & 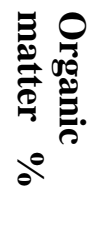 & $\begin{array}{l}\widehat{\Omega} \\
\hat{\jmath} \\
\hat{\omega} \\
0\end{array}$ \\
\hline & 70.10 & 22.60 & 7.30 & $\begin{array}{l}\text { Sandy } \\
\text { loam }\end{array}$ & 7.60 & 8.00 & 0.51 & 0.45 & 1.25 & 0.05 & 11.50 \\
\hline
\end{tabular}

Seeds: seeds of fennel were obtained from Research Center of Medicinal and Aromatic Plants, Ministry of Agriculture, Egypt. Five seeds were sown in each pot $(30 \mathrm{~cm}$ diameters and $50 \mathrm{~cm}$ height) filled with air dried sandy loam soil $(20 \mathrm{~kg} / \mathrm{pot})$ on $1^{\text {st }}$ November in the two successive seasons. One month later, the seedlings were thinned to one plant/ pot. Plants were irrigated and hand weeded regularly according to its needs.

Fertilization: All fennel plants including control were fertilized with NPK full recommended dose by Ministry of Agriculture were, Ammonium nitrate $(33.5 \% \mathrm{~N})$ at the rate of $250 \mathrm{Kg} / \mathrm{fed}$. (5 g/ pot); Calcium superphosphate

Fayoum J. Agric. Res. \& Dev., Vol.23, No.1,(B). January, 2009 
$\left(15.5 \% \mathrm{P}_{2} \mathrm{O}_{5}\right)$ at the rate of $150 \mathrm{~kg} / \mathrm{fed} .(3 \mathrm{~g} / \mathrm{pot})$ and $50 \mathrm{~kg} / \mathrm{fed}$. Potassium sulphate $\left(48 \% \mathrm{~K}_{2} \mathrm{O}\right)$ at the rate of $50 \mathrm{~kg} / \mathrm{fed}$. $(1 \mathrm{~g} / \mathrm{pot})$.

Nitrogen fertilizer was divided into two equal doses, after 30 and 60 days from sowing. While, $\mathrm{P}$ and $\mathrm{K}$ fertilizers were added during soil preparation.

Antioxidants: Plants treated with ascorbic, citric acids and vitamins B at the rates of 100,250 and $500 \mathrm{ppm}$ for each one, in addition to the control treatment were sprayed only with distilled water. Antioxidants at mentioned concentration were sprayed on the foliage of plants to run off. The plants were sprayed with two doses of aqueous solution (contained few drops of Triton B as a wetting agent) of each tested compound along with tap water as control at age of 30 and 60 days from sowing.

The experiment design used was randomized complete blocks, with three replications. Each experiment unit contained eight pots.

Data recorded :

1- Vegetative growth parameters:

At the age of 150 days (During vegetative stag), 4 plants were randomly chosen from each experimental unit and cut off at ground level and submitted to the following determinations: plant height $(\mathrm{cm})$, number of branches/plant, fresh and dry weight of plant (g). .(the samples were dried in an electric oven at $70 \mathrm{C} \pm 2$ till constant weight and then ground to determine the chemical constituents).

\section{2- Yield and its components :}

At full maturity fruit stage (180 days), the umbels of 4 plants were randomly chosen from each experimental unit, to estimation the following yield characters, number of umbels (inflorescences)/ plant, diameter of umbels (cm) and fresh and dry weights of umbels/ plant ( $\mathrm{g})$, as well as weight of seeds / plant $(\mathrm{g})$.

\section{3- Chemical constituents :}

- In fresh leaves at the age of 150 days, total chlorophylls and carotenoids concentrations ( $\mathrm{mg} \mathrm{g}^{-1}$ fresh weight of leaf) were determined using colorimetric method as described by Welburn and Lichtenthaler (1984).

While, the following chemical constituents were determined in both seasons in powdered dry leaves:

Total carbohydrates $(\%)$ were colorimetrically determined according to the method described by Herbert et al., (1971). Nitrogen (\%) was calorimetrically determined by using the Orange $\mathrm{G}$ dye according to the method of Hafez and Mikkelsen (1981). The volatile oil percentage was extracted by water distillation according to Guenther (1961). The obtained volatile oil was dehydrated over unhydrus sodium sulphate and then performed by GLC analysis with varian. VISTA ser 6000, FID model. The separation was carried out by $2 \mathrm{~m} \mathrm{X} 1 / 8$ in o-d-stainless steel $3 \% \mathrm{OV}-101$ column. The carrier gas (nitrogen) flow rate $50 \mathrm{ml} / \mathrm{min}$ was maintained while the column temperature was programmed from 80 to $200^{\circ}$ at a rate of $4 \% \mathrm{~min}$. the injection port temperature was maintained at $180^{\circ}$ and detector at $240^{\circ}$. The relative percent of each compound was determined by varian 4270 integrater.

The results were statistically analysis using the LSD at probability level of $5 \%$ for comparison (Gomez and Gomez, 1983).

Fayoum J. Agric. Res. \& Dev., Vol.23, No.1,(B). January, 2009 
RESULTS AND DISCUSSION

1) Vegetative growth characters:

Statistical data cleared that, the treated fennel plants by ascorbic, citric acid and vitamin B at the concentrations of 100, 250 and $500 \mathrm{ppm}$. gave the positive effect on vegetative growth parameters, in the two successive seasons as compared to the untreated plants.

\section{1-1- Plant height:}

Data presented in Table (2) show that, all treatments of antioxidants on fennel plants significantly increased plant height as compared to the control except the level of $100 \mathrm{ppm}$ for both ascorbic acid and citric acid were insignificantly. The higher significant means values observed with $500 \mathrm{ppm}$. in vitamin B and ascorbic acid that appeared the higher response reached to ( 24.25 and $23.89 \%$ ) above the control in the first season, respectively. The same trend was observed in the second season.

\section{2-1- Number of branches / plant:}

Results recorded in (Table 2) show that, all application rates of antioxidants increased the mean number of branches plant ${ }^{-1}$ as compared to control. But, it was noticed that the effect of citric acid was insignificant with all concentrations, and also, with the treatments 100 and $250 \mathrm{ppm}$. for ascorbic acid and treatment $100 \mathrm{ppm}$. for vitamin B. On the other hand, the maximum increase of the number of branches plant ${ }^{-1}$ was obtained by the treatment $500 \mathrm{ppm}$. of vitamin B (36.4\%) followed by treatment $500 \mathrm{ppm}$. of ascorbic acid $(27.3 \%)$ as compared with the control plants. The same line was observed in the second one.

Table (2): Effect of ascorbic acid, citric acid and vitamin $B$ on vegetative growth of fennel plants grown under saline soil conditions.

\begin{tabular}{|c|c|c|c|c|c|c|c|c|c|}
\hline \multicolumn{2}{|c|}{ Characters } & \multirow{2}{*}{$\begin{array}{l}\text { Plant } \\
\text { height } \\
(\mathrm{cm})\end{array}$} & \multirow{2}{*}{$\begin{array}{l}\text { No. of } \\
\text { branch. } \\
\text { plant }^{-1}\end{array}$} & \multirow{2}{*}{$\begin{array}{l}\text { F.W. of } \\
\text { herb } \\
\text { plant }^{-1} \\
(\mathrm{~g})\end{array}$} & \multirow{2}{*}{$\begin{array}{c}\text { D.W. of } \\
\text { herb } \\
\text { plant }^{-1} \\
(\mathrm{~g})\end{array}$} & \multirow{2}{*}{$\begin{array}{l}\text { Plant } \\
\text { height } \\
(\mathrm{cm})\end{array}$} & \multirow{2}{*}{$\begin{array}{l}\text { No. of } \\
\text { branch. } \\
\text { plant }^{-1}\end{array}$} & \multirow{2}{*}{$\begin{array}{l}\text { F.W. of } \\
\text { herb } \\
\text { plant }^{-1} \\
\text { (g) }\end{array}$} & \multirow{2}{*}{$\begin{array}{l}\text { D.W. of } \\
\text { herb } \\
\text { plant }^{-1} \\
\text { (g) }\end{array}$} \\
\hline Treatm & nts & & & & & & & & \\
\hline \multirow{2}{*}{\multicolumn{2}{|c|}{ Control }} & \multicolumn{4}{|c|}{ First season } & \multicolumn{4}{|c|}{ Second season } \\
\hline & & 56.50 & 5.50 & 53.84 & 12.16 & 58.90 & 5.74 & 56.13 & 12.68 \\
\hline \multirow{3}{*}{ Ascobic } & 100 & 59.00 & 6.00 & 58.00 & 14.36 & 61.50 & 6.25 & 60.46 & 14.97 \\
\hline & 250 & 65.00 & 6.50 & 61.09 & 15.43 & 67.77 & 6.78 & 63.69 & 16.09 \\
\hline & 500 & 70.00 & 7.00 & 64.52 & 16.15 & 72.98 & 7.30 & 67.26 & 16.63 \\
\hline \multirow{3}{*}{ Citric } & 100 & 58.50 & 6.00 & 56.00 & 12.11 & 60.99 & 6.25 & 58.38 & 12.62 \\
\hline & 250 & 61.20 & 6.00 & 60.21 & 15.50 & 63.81 & 6.26 & 62.77 & 16.16 \\
\hline & 500 & 66.30 & 6.50 & 64.00 & 16.00 & 69.11 & 6.78 & 66.72 & 16.68 \\
\hline \multirow{3}{*}{$\begin{array}{c}\text { Vitamin } \\
\text { B }\end{array}$} & 100 & 59.60 & 6.50 & 60.51 & 15.85 & 62.13 & 6.78 & 63.08 & 16.52 \\
\hline & 250 & 63.40 & 7.00 & 64.21 & 15.95 & 66.10 & 7.30 & 66.94 & 16.84 \\
\hline & 500 & 70.20 & 7.50 & 68.31 & 17.28 & 73.18 & 7.82 & 71.21 & 18.01 \\
\hline \multicolumn{2}{|c|}{ LSD 5\% } & 2.66 & 1.08 & 0.81 & 0.33 & 2.77 & 1.13 & 0.83 & 0.34 \\
\hline
\end{tabular}

Fresh and dry weights of herb plant ${ }^{-1}$ :

Plants of fennel were significantly enhanced due to different treatments of ascorbic acid, citric acid and vitamin B either in the first or second seasons Table (2) except the treatment $100 \mathrm{ppm}$. of citric acid was insignificant in the case of herb dry weight. The greatest increase of fresh and dry weights of herb plant $^{-1}$ was obtained by the highest rate of vitamin B or ascorbic acid (500 ppm.) which reached, 26.88 and $42.11 \%$ and by, (19.84 and $32.81 \%$ ) then

Fayoum J. Agric. Res. \& Dev., Vol.23, No.1,(B). January, 2009 
followed by the treatment $250 \mathrm{ppm}$. of vitamin $\mathrm{B}$, which found to be, 19.26 and $31.17 \%$, respectively, over control in the first season. The same trend was obtained in the second season.

The increasing endogenous antioxidants i.e ascorbic, citric acid and vitamin $B$ as a result of application by them leads to protect plant cells and consequently, protect the photosynthetic apparatus by scavenging reactive oxygen species (Zhang and Schmidt, 2000) thus, vigorous plant growth will be obtained under stress conditions. Also, Prusky (1988) and Elade (1992) reported a positive action for antioxidants on growth and attributed this finding to their effects on counteracting drought, salinity and diseases stresses and protecting plant cells against free radicals that responsible for plant senescence as well as to their auxinic action and consequently, enhancing growth characters. In addition, antioxidants might be regulates cell wall expansion, cell division and elongation through its action in cell vacuolarization (Navas and Gomez-Diaz, (1995) and Cordoba Pedregosa et al., (1996).

The beneficial effect of ascorbic, citric acid and vitamin B on vegetative growth are in agreement with those obtained by Tarraf et at., (1999) on lemongrass, Bardisi (2004) on garlic, Ahmed (2005) on Majorana hortensis, Rady, (2006) on sunflower plants, Abd El-Latif (2007) on borage and Ahmed (2007) on datura and Abdullahi et at., (2004) on soybean .

2) Yield and its components:

\section{2-1- Number of umbels plant ${ }^{-1}$ :}

The results obtained in Table (3) clearly show that all treatments of antioxidants increased number of umbels plant ${ }^{-1}$.but the increasing was insignificant with the concentrations 100 and $250 \mathrm{ppm}$. of citric and ascorbic acid, also, with the treatment $100 \mathrm{ppm}$. of vitamin $\mathrm{B}$, as compared to the control at the first and second seasons. The highest values of increase in the number of umbels plant ${ }^{-1}$ resulted from the treatments $500 \mathrm{ppm}$ of vitamin B $(31.58 \%)$ or ascorbic acid $(26.32 \%)$ and then the treatment $250 \mathrm{ppm}$. of vitamin B $(21.05 \%)$, over the control plants in the first season. The same trend was generally obtained in the second season.

\section{Diameter of umbel :}

Statistical data in (Table 3) show that the diameter of umbel was increased by increasing the rates of antioxidants. The slightly increase of umbel diameter was obtained by the treatment $100 \mathrm{ppm}$. in all antioxidants compounds. On the other hand, the other treatments were significant in both test seasons (Table 3). The highest increase of diameter of umbel was resulted from the treatment $500 \mathrm{ppm}$ vitamin B or ascorbic acid (28.05 and $19.51 \%$, respectively) in comparison to the control plants at the first season. The same result was obtained in the second season.

\section{2-3 - Fresh and dry weights of umbels plant ${ }^{-1}$ :}

Data obtained in (Table 3) indicated that fresh and dry weights of umbels plant $^{-1}$ were significantly increased as a result of the different treatments of vitamin B, citric and ascorbic acid as compared to control either in the first or second season. The maximum increase in fresh and dry weights of umbels plant $^{-1}$ was obtained from vitamin B followed by ascorbic acid, especially, at the rates 500 and $250 \mathrm{ppm}$. of vitamin $\mathrm{B}$, were (74.27and 79.79) and (55.26 and $67.97 \%$ ), respectively, followed by the treatment $500 \mathrm{ppm}$. of ascorbic acid, reached, 49.56 and $70.60 \%$, respectively, in comparison to the untreated

Fayoum J. Agric. Res. \& Dev., Vol.23, No.1,(B). January, 2009 
plants at the first season. The same trend was generally obtained in the second season.

\section{2-4 - Weight of seeds plant ${ }^{-1}$ :}

Data recorded in Table (3) show that the weight of fennel seeds plant ${ }^{-1}$ was significantly affected by foliar application of vitamin B, ascorbic and citric acid at different concentrations compared to control plants in the two experimental seasons. The best results were obtained by the treatment 500 ppm. of vitamin B followed by $500 \mathrm{ppm}$. ascorbic acid and the treatment 250 ppm. Vitamin B. which were, 69.00, 66.25 and $61.88 \%$, respectively, over the control in the first season. The similar trend was observed in the second season.

Table (3): Effect of ascorbic acid, citric acid and vitamin B on yield and its components of fennel plants grown under saline soil conditions.

\begin{tabular}{|c|c|c|c|c|c|c|c|}
\hline \multicolumn{2}{|c|}{ Characters } & $\begin{array}{l}\text { No. of } \\
\text { umbels } \\
\text { plant }^{-1}\end{array}$ & $\begin{array}{l}\text { Diameter } \\
\text { Of } \\
\text { umbel } \\
(\mathrm{cm})\end{array}$ & $\begin{array}{l}\text { F.W. of } \\
\text { umbels } \\
\text { plant }^{-1} \\
(\mathrm{~g})\end{array}$ & $\begin{array}{l}\text { D.W. of } \\
\text { umbels } \\
\text { plant }^{-1} \\
(\mathrm{~g})\end{array}$ & $\begin{array}{l}\text { W. of } \\
\text { seeds } \\
\text { plant }^{-1} \\
(\mathrm{~g})\end{array}$ & $\begin{array}{c}\text { Oil } \\
\text { yield/ } \\
\text { plant } \\
\%\end{array}$ \\
\hline \multicolumn{8}{|c|}{\begin{tabular}{l|c|c} 
Treatments & $(\mathrm{cm})$ & $(\mathrm{g})$ \\
\end{tabular}} \\
\hline \multicolumn{2}{|l|}{ Control } & 9.50 & 8.20 & 15.78 & 3.81 & 8.00 & 1.20 \\
\hline \multirow[t]{3}{*}{ Ascobic } & 100 & 10.00 & 8.50 & 18.92 & 5.05 & 11.51 & 1.65 \\
\hline & 250 & 10.50 & 9.00 & 22.50 & 6.10 & 12.21 & 1.68 \\
\hline & 500 & 12.00 & 9.80 & 23.60 & 6.50 & 13.00 & 1.70 \\
\hline \multirow[t]{3}{*}{ Citric } & 100 & 9.50 & 8.70 & 18.50 & 5.21 & 11.15 & 1.64 \\
\hline & 250 & 10.00 & 9.20 & 22.00 & 6.30 & 12.52 & 1.68 \\
\hline & 500 & 10.75 & 9.70 & 23.00 & 6.18 & 12.95 & 1.69 \\
\hline \multirow{3}{*}{$\begin{array}{l}\text { Vitamin } \\
\text { B }\end{array}$} & 100 & 10.00 & 8.90 & 20.00 & 5.41 & 11.52 & 1.67 \\
\hline & 250 & 11.50 & 9.50 & 24.50 & 6.40 & 13.30 & 1.69 \\
\hline & 500 & 12.50 & 10.50 & 27.50 & 6.85 & 13.52 & 1.82 \\
\hline \multicolumn{2}{|l|}{ LSD 5\% } & 1.16 & 0.73 & 0.95 & 0.16 & 0.46 & 0.04 \\
\hline \multicolumn{8}{|c|}{ Second season } \\
\hline \multicolumn{2}{|l|}{ Control } & 9.91 & 8.55 & 16.45 & 3.97 & 8.69 & 1.22 \\
\hline \multirow[t]{3}{*}{ Ascobic } & 100 & 10.43 & 8.86 & 19.73 & 5.26 & 12.00 & 1.72 \\
\hline & 250 & 10.95 & 9.38 & 23.46 & 6.36 & 12.73 & 1.75 \\
\hline & 500 & 12.51 & 10.22 & 24.61 & 6.78 & 13.30 & 1.78 \\
\hline \multirow[t]{3}{*}{ Citric } & 100 & 9.92 & 9.07 & 19.28 & 5.43 & 11.62 & 1.71 \\
\hline & 250 & 10.42 & 9.59 & 22.93 & 6.57 & 13.05 & 1.75 \\
\hline & 500 & 11.21 & 10.11 & 23.98 & 6.44 & 13.50 & 1.76 \\
\hline \multirow{3}{*}{$\begin{array}{c}\text { Vitamin } \\
\text { B }\end{array}$} & 100 & 10.42 & 9.28 & 20.85 & 5.64 & 12.01 & 1.74 \\
\hline & 250 & 11.99 & 9.90 & 25.54 & 6.67 & 13.57 & 1.76 \\
\hline & 500 & 13.04 & 10.95 & 28.67 & 7.14 & 14.10 & 1.90 \\
\hline \multicolumn{2}{|l|}{ LSD 5\% } & 1.21 & 0.76 & 1.00 & 0.17 & 0.48 & 0.04 \\
\hline
\end{tabular}

\section{2-5- Yield of oil :}

Data presented in (Table 3) show that the yield of oil / plant of fennel was increased by increasing the rates of antioxidants. The maximum increase of oil / plant was obtained by the treatment $500 \mathrm{ppm}$ of vitamin $\mathrm{B}$, or ascorbic acid, reached, 51.67and 41.67\%, respectively, as compared to the untreated plants, in the first season. The same trend was obtained in the second season.

The positive effect of antioxidants on yield of seeds and oil mainly may be due to its improving action on enhancing vegetative growth parameters

Fayoum J. Agric. Res. \& Dev., Vol.23, No.1,(B). January, 2009 
(Table 2), photosynthetic pigments of plant leaves and metabolism of other organic compounds i.e total carbohydrates (Table 4) for sustenance of cells turgor leading to maintenance of metabolic activities in plants and plant nutritional status. Also, Al-Qubaie (2002) stated that antioxidants such as vitamin $\mathrm{B}$, ascorbic and citric acid has an auxinic action and also synergistic effect on the biosynthesis of carbohydrates and controlling the incidence of most fungi on plants makes them in vigouor states and reflects on yield of seed and oil . Besides, the induced effect of ascorbic acid as one of vitamins are recognized to be coenzyme involved in specific biochemical reactions in plants such as oxidative and nonoxidative decarboxylations (Rbinson, 1973). Also, Tarraf et al., (1999) reported that the increase in essential oil content of lemongrass as a result of the foliar application with ascorbic acid.

The increment of yield and its components and oil percentage of fennel plants due to antioxidants was obtained by Mohamed and Naguib (2002) on fenugreek, Al-Shareif (2006) on Coriandrum sativum, Rady (2006) on sunflower and Ahmed (2007) on datura regarding the influence of ascorbic acid.

\section{3) Chemical constituents:}

-Total chlorophylls, carotenoids, total carbohydrates and nitrogen concentrations :-

Data in Table (4) revealed that the treated fennel plants with ascorbic, citric acid and vitamin B significantly increased total chlorophylls, carotenoids, total carbohydrates and nitrogen concentrations in comparison with the untreated plants in both test seasons. The maximum increase was obtained by the treatment $500 \mathrm{ppm}$. of vitamin B followed by $500 \mathrm{ppm}$. of ascorbic acid, which reached, 16.23 and $15.29 \%$ for total chlorophylls; 46.34 and $45.85 \%$ for carotenoids; 5.14 and $4.47 \%$ for total carbohydrates and 7.87 and $6.74 \%$ for nitrogen, respectively, as compared to the control plants at the first season. The similar trend was observed in the second season.

\section{Essential oil components:}

Chromatographic analysis of fennel oil samples revealed that Anethole and g-Terpinene are its main components (Table 5). All treatments led to increase the anethole percentage compared to control. The highest content was found in the oil of plants receiving $500 \mathrm{ppm}$. (vitamin B) then $500 \mathrm{ppm}$. (ascorbic acid). On the other hand, the g-Terpinene content decreased in treated plants than in the control. Also, fenchyl acetate and fenchone decreased except the treatments 500ppm ascorbic acid and $250 \mathrm{ppm}$. vitamin B. But, the highest limonene content was found that in the oil of plants receiving $100 \mathrm{ppm}$. ascorbic acid and $500 \mathrm{ppm}$. vitamin B. 
Matter, F. M. A.

Table (4): Effect of ascorbic acid, citric acid and vitamin $B$ on some chemical constituents of fennel plants grown under saline soil conditions.

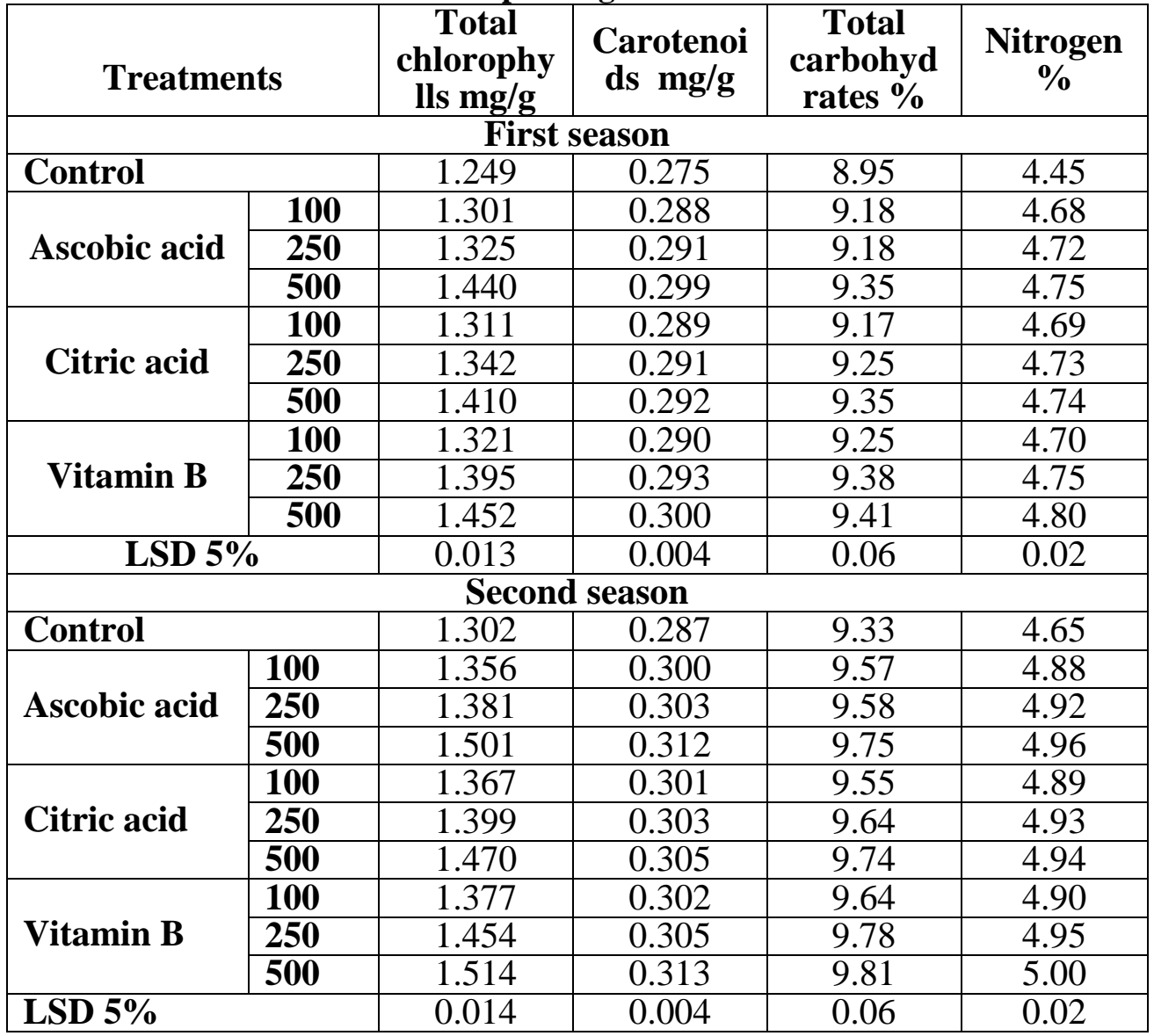

The effect of antioxidants on chemical constituents of fennel plants was supported by Mohamed and Naguib (2002) on fenugreek, Al-Shareif (2006) on Coriandrum sativum, Rady (2006) on sunflower and Ahmed (2007) on datura regarding the influence of ascorbic acid.

The role of antioxidants which directly involved in the regulation and protection of photosynthetic processes (Farago and Brunold, 1994) could be led to the enhancing effect of antioxidants on photosynthetic pigments under study (Table 4). This may be explained by the findings of Foyer et al., (1990) who stated that, the antioxidants prevented enzyme inactivation, the generation of more dangerous radicals and allowed flexibility in the production of photosynthetic assimilatory power. Moreover, electron transfer to $\mathrm{O} 2$ prevented over reduction of electron transport chain, which reduced the risk of harmful back reactions within the photosystem. Alas, Elade, (1992) stated that most antioxidants were responsible for accelerating the biosynthesis of various pigments. The increasing photosynthetic activity reflect on organic compound biosynthesis i.e carbohydrates content in plant. The ability to defend plant cells against oxidative damage resulting from salinity stress is directly correlated with the level of anioxidants such as ascorbate, glutathione and $\alpha$ - tocopherol (Wise and Naylor, 1987).

Fayoum J. Agric. Res. \& Dev., Vol.23, No.1,(B). January, 2009 
PHYTOCHEMICAL STUDIES ON GROWTH, YIELD AND.

Table (5): Effect of ascorbic, citric acid and vitamin $B$ on percentage of oil components of fennel plants grown under saline soil conditions.

\begin{tabular}{|c|c|c|c|c|c|c|c|c|c|c|}
\hline 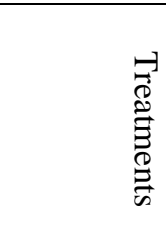 & 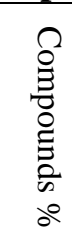 & 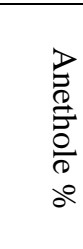 & 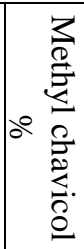 & 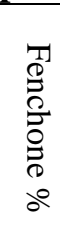 & 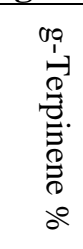 & 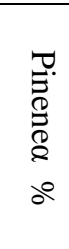 & 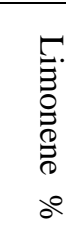 & $\begin{array}{l}\underset{1}{+} \\
\frac{1}{0} \\
\stackrel{0}{0} \\
\stackrel{0}{0} \\
\partial^{2}\end{array}$ & $\begin{array}{l}\frac{D}{0} \\
\frac{0}{0} \\
0 \\
0 \\
0\end{array}$ & 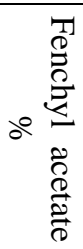 \\
\hline \multicolumn{2}{|c|}{ Control } & 47.2 & 1.8 & 0.4 & 35.5 & 0.3 & - & 0.4 & 2.4 & 7.9 \\
\hline \multirow{3}{*}{$\begin{array}{c}\text { Ascobic } \\
\text { acid }\end{array}$} & 100 & 57.8 & 2.3 & 0.6 & 1.3 & 0.2 & 9.5 & 0.3 & 6.2 & 3.4 \\
\hline & 250 & 67.1 & 2.0 & 0.2 & 13.0 & - & 3.7 & - & 1.1 & 4.1 \\
\hline & 500 & 75.7 & 2.3 & - & 4.3 & - & 3.5 & - & 0.1 & 8.3 \\
\hline \multirow[t]{3}{*}{ Citric acid } & 100 & 56.0 & 1.7 & 0.3 & 28.2 & 0.1 & 0.1 & 0.1 & 3.4 & 6.7 \\
\hline & 250 & 60.3 & 2.2 & 0.2 & 17.9 & 0.2 & 1.1 & - & 0.1 & 5.7 \\
\hline & 500 & 68.4 & 2.1 & 0.1 & 15.1 & 0.1 & 2.4 & 0.4 & 1.4 & 5.1 \\
\hline \multirow[t]{3}{*}{ Vitamin B } & 100 & 60.8 & 2.1 & 0.2 & 25.5 & 0.3 & - & 0.8 & 1.1 & 4.4 \\
\hline & 250 & 72.1 & 3.7 & 1.3 & 11.0 & - & 3.7 & - & - & 2.5 \\
\hline & 500 & 80.2 & 2.0 & - & 0.8 & - & 9.4 & - & 1.7 & 2.7 \\
\hline
\end{tabular}

\section{CONCLUSION}

It is clear from the previous results that, the harmful effect of saline soil conditions on growth and productivity of fennel plants can be reducing by foliar application of plants with antioxidants such as Ascorbic acid, citric acid and vitamins $\mathrm{B}$ and improved the growth and productivity of fennel plants especially at the rate of $(500 \mathrm{ppm})$. These may be due to the promoting effects of antioxidants substances on fennel plants which could be explained in the light of the biological and physiological functions of these antioxidant as follows: vitamin $\mathrm{B}$ and ascorbic acid protects chloroplast and election transport system. Also, stimulates respiration activities, cell division and many enzymes activities. These regulates cell elongation and expansion and acts as co-enzyme in the enzymatic reactions by which carbohydrates, fats and proteins are metabolized, as well as, these have been suggested as a hormones. (Robinson, 1973, Givan, 1979, Bearder, 1980, Helsper, et al., 1982, Oertli, 1987 and Dewick, 2000).

\section{REFERENCES}

Abbas, M.A.; Younis, M.E. and Shukry, W.M. (1991): plant growth metabolism and adaptation in relation to stress conditions. III.effect of salinity on the internal solute concentrations in Phaseolus vulgaris. J. Plant Physiol., 138: 722- 729.

Abd El-Latif, M.T.M (2007): Effect of some fertilization and antioxidant treatments on borage plants. M.Sc. Thesis, Fac. Agric. Minia Univ., Egypt.

Abdullahi, B.A.; P. Huang; M.X. Ying; S.H. Guan and Y. Yong- Hua (2004): Effect of citric acid on soybean seedling growth under aluminum stress. J. of plant nutrition 27 (2): 367-375.

Ahmed, E.T. (2007): Response of Datura stramonium, L. plants to the application of kristalon, ascorbic acid under different NPK fertilization rates. Minia J. of Agric. Res.\& Develop. Vol (27) No.4: 713-736.

Fayoum J. Agric. Res. \& Dev., Vol.23, No.1,(B). January, 2009 
Ahmed, M.T. (2005): Physiological studies on marjoram plants (Majorana hortensis, M.). M.Sc. Thesis, Fac. Agric. Moshtohor, Zagazig Univ., Egypt.

Al-Qubaie, A.I. (2002): Response of Ficus nitida L. seedlings to the application of some antioxidants under soil salinity conditions. Minia J. of Agric. Res. \& Develop., 22 (3): 235 - 254.

Al-Shareif, A.M.O. (2006): Response of caraway plants grown in sandy soil under drip irrigation system to some biofertilization and antioxidant treatments. M.Sc. Thesis, Fac. Agric. Minia Univ., Egypt.

Bardisi, A. (2004): influence of vitamin C and salicylic acid foliar application on garlic plants under sandy soil conditions. 1- Growth and plant chemical composition. Zagazig j. Agric. Res., 31 (4A): 1335-1347.

Bearder, J.R. (1980): Plant hormones and other growth substances their background, structures and occurrence. J. Macmillan (Ed.). Encyclopedia of Plant Physiol., 9: 9-112.

Cordoba- Pedregosa, M.C.; Gonzalez- Reyes, J.K.; Sandillas, M.S.; Navas, P. and Cordoba, F. (1996): Role of apoplastic and cell wall peroxidases on the stimulation of root elongation by ascorbate. Plant Pathol., 112: $1119-1125$.

Dewick, P.M. (2000): Medicinal Natural Products. A Biosynthetic Approach $2{ }^{\text {nd }}$ Ed., John Wiley \& Sons, N, Y., 306-356.

Elade, Y. (1992): The use of antioxidants to control gray mould (Botrytis cineria) and white mould (Sclerotinia sclerotiorum) in various crops. Plant Pathol., 141: 417 - 426.

Farago, S. and Brunhold, C. (1994): Regulation of thiol contents in maize roots by intermediates and effectors of glutathione synthesis. J. Plant Physiol., 144 : $433-437$.

Foyer, C.H.; Furbank, R.T.; Harbinson, J. and Horton, P. (1990): The mechanism contributing to photosynthetic control of electron transport by carbon assimilation in leaves. Photosynth. Res., 25: 83100.

Foyer, C.H. and Halliwell, B. (1976): The presence of glutathione and glutathione reductase in chloroplasts: A proposed role in ascorbic acid metabolism. Planta 157: 239- 244 .

Givan, G.V. (1979): Metabolic detoxification of ammonia in tissues of higher plants. Phytochemistry, 18: 375-382.

Gomez, K.A. and Gomez, A.A.(1983): Statistical Procedure For Agricultural Research. A Wiley Inter-Science Publication. John Wiley \& Sone Inc. New York.

Greenway, H. and Munns, R. (1980): Mechanisms of salt tolerance in Nonhalophytes . Ann. Rev. Plant Physiol., 31: 149- 190.

Guenther, E. (1961): "The Essential oil" Vol. I. D. van Nostrand Cam INC., New York.

Hafez, A. and D.S. Hikkelsen (1981): Colorimetric determination of nitrogen for evaluating the nutritional status of rice. Commnu. Soil Sci. and Plant Analysis, 12 (1): 16-69.

Helsper, J.P.; C.L. Kagan; J.M. Maynard and F.A. Loewas (1982): Ascorbic acid biosynthesis on chromonas danica. Plant Physiol., 69: 465-468.

Herbert, D.; P.J. Phipps and R.E. Strange (1971) Methods in Microbiology, 5 B, Academic Press, London, 209-344.

Fayoum J. Agric. Res. \& Dev., Vol.23, No.1,(B). January, 2009 
Innocenti, M.A.; Bitonti, M.; Arrigoni, O. and Liso, R. (1990): The size of quiescent center in roots of Allium cepa $\mathrm{L}$. grown with ascorbic acid. New Phytol., 114: 507 - 509.

Marotti, M.; R. Piccaglia and E. Giovanelli (1994): Effects of variety and ontogenetic stage on the essential oil composition and biological activity of fennel (Foeniculum vulgare Mill.). J. Essential Oil Res, 6:57-62.

Mass, E.V. (1986): Crop tolerance to saline soil and water. Proc. US. Pak. Biosaline Res. Workshop, Botany Dept., Karachi Univ., Pakistan, pp. $205-219$.

Mohamed, S.A. and N.Y. Naguib (2002): Enfluence of foliar sprays with potassium $\mathrm{P}, \mathrm{N}$, ascorbine and their compinations on yield parameters and chemical constituents of seeds of fenugreek plants. Arab. Univ. J. Agric. Sci., Ain Shams Univ., Cairo, 10(3):879-891.

Navas, P. and Gomez - Diaz, C. (1995): Ascorbic free radical and its role in growth control. Protoplasm, 184: $8-13$.

Oertli, J.J. (1987): Exogenous application of vitamins as regulators for growth and development of plant. A review Z. planzenernahr. Bodenk., 150: 375-391.

Olsen, S.R. and Sommers, L.E. (1982): Phosphorus, In: Methods of Soil Analysis. Part2, pp.403-430. Page, A.I., Miller, R.H. and Keeny, T.R. (eds.), Am. Soc. of Agron. Madison WI.

Page, A.I.; R.H. Miller and T.R. Keeny (Eds.) (1982): Methods of Soil Analysis. Part 2: 595 . Am. Soc. of Agron., Madison WI 9.USA.

Prusky, D. (1988): The use of antioxidants to delay the onset of anthracnose and stem end decay in avocado fruits after harvest. Plant Disease, 72: $381-384$.

Rady, M.M. (2006): Efficiency of growth and productivity of sunflower plants as affected by ascorbic acid under saline reclaimed soil conditions. The Second Conference on Farm Integrated pest Management 16-18 Jan.2006, at Fac. of Agic., Fayoum Univ.

Rautenkranz, A.; Machler, F.; Martinoia, E. and Oertli, J. (1994): Transport of ascorbic acid and dehydroascorbic acids across protoplast and vacuole membranes isolated from barley ( Hoedeum vulgare L. cv. Gebrel) leaves. Plant Physiol., 106: 187 -193.

Robinson, F.A. (1973): Vitamins. In: Phytochemistry Lawrence P. Miller (Ed.) Van- Nostrand Reinhold Co. New York, 3: 195-220.

Scandalios, J.G. (1997): Molecular genetics of superoxide dismutases in plants. Pp. 527-568. In: Scandalios, J. G. (ed). Oxidative stress and the molecular biology of antioxidant defenses. Cold Spring Harbor Lab. Press. Plainview, N.Y.

Tarraf, S.A.; Gamal, El-Din, K.M. and Balbaa, L.K. (1999); The response of vegetative growth, essential oil of lemongrass (Cymbopogon citrates. Hort.) to foliar application of ascorbic acid, nicotinamide and some micronutrients. Arab Univ. J. Agric. Sci., Ain Shams Univ., Cairo, 7 (1) : $247-261$.

Welburn, A.R. and H. lichtenthaler, (1984): Formula and program to determine total carotenoids and chlorophyll $\mathrm{a}$ and $\mathrm{b}$ of leaf extracts in different solvents. "Advances in Photosynthesis Research" (Sybesma C. Ed.) Vol. П, pp. 9-12.

Fayoum J. Agric. Res. \& Dev., Vol.23, No.1,(B). January, 2009 
Matter, F. M. A.

Wise, R.R. and Naylor, A.W. (1987): The peroxiddative destruction of lipids during chilling injury of photosynthesis and ultrastructure. Plant Physiol., 83: $272-277$.

Zhang, X. and Schmidt, R.E. (2000): Hormone - contaning prducts impact on antioxidant status of tall fescue and creeping bentgrass subjected to drought. Crop Sci., 40: 1344 - 1349.

دراسات نباتية وكيميائية علي النمو والمحصول والتركيب الكيماوي لنباتات الثمر وتأثرها بمضادات الأكسدة تحت ظروف الأرض وض المستصلحة الملحية

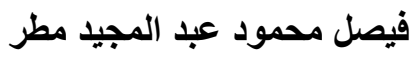

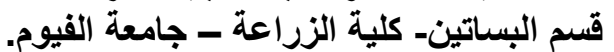

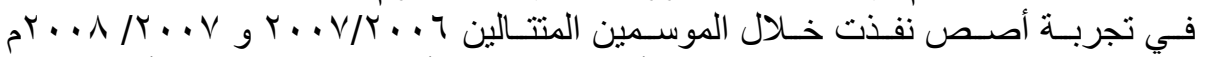

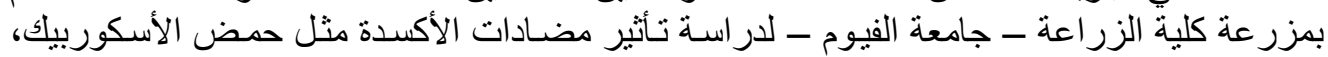

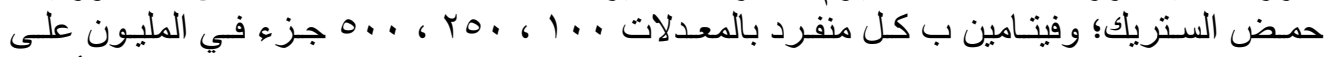

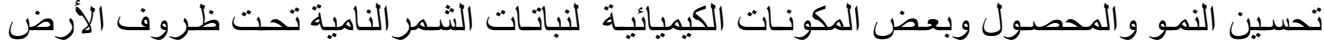

الملحية المستصلحة.

- أظهرت النتائج المتحصل علئهة اليها أن معاملة نباتات الثـمر بحمض الأسكوربيك، حمض الستريك؛

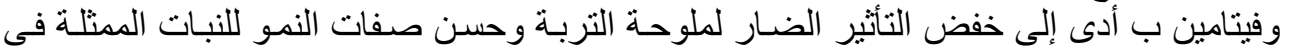

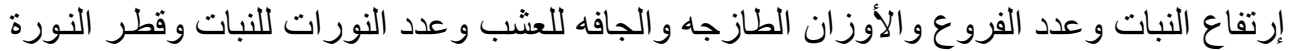

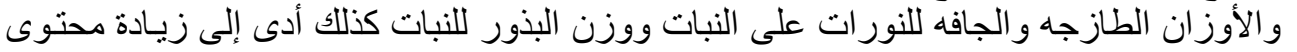

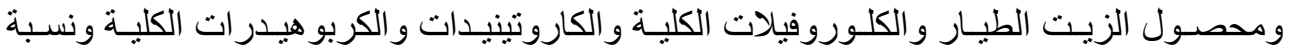

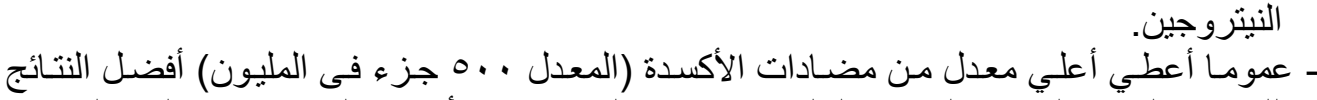

للصفات النباتية السابقة بالترتيب التالي فيتامين ب يليه حمض الأسكوربيك ثم حمض الستريك.

Fayoum J. Agric. Res. \& Dev., Vol.23, No.1,(B). January, 2009 